DOI: 10.32844/2222-5374-2020-104-2.46

УДК: 343.98

Пиняга Р. О.,

кандидат юридичних наук

\title{
ОБСТАВИНИ, ЩО ПІДЛЯГАЮТЬ ДОКАЗУВАННЮ НА ПОЧАТКОВОМУ ЕТАПІ РОЗСЛІДУВАННЯ КРИМІНАЛЬНИХ ПРАВОПОРУШЕНЬ, ПОВ'ЯЗАНИХ ІЗ ЗАЙНЯТТЯМ ГРАЛЬНИМ БІЗНЕСОМ
}

\begin{abstract}
У статті деталізовано предмет доказування з урахуванням криміналістичної характеристики кримінальних правопорушень, пов'язаних із зайняттям гральним бізнесом. Визначено, що до події кримінального правопорушення належать насамперед технологія та спосіб зайняття гральним бізнесом, час і місце його вчинення. Встановлення винуватості обвинуваченого, форми вини, мотиву ймети вчинення кримінального правопорушення має на меті визначення кількості осіб, причетних до кримінального правопорушення, характеру розподілу ролей між ними, даних про фігурантів (вік, осудність, ознаки зовнішності, професійні навички), інших ознак, що характеризують ту чи іншу форму співучасті (кількість співучасників, стійкість, попередня змова чи зорганізованість, мета діяльності, наявність плану). Також необхідно встановити спосіб легалізації доходів, одержаних злочинним шляхом. З'ясовано, що для розслідування злочинів, пов'язаних із зайняттям гральним бізнесом, важливе значення має розроблення обставин, що підлягають доказуванню. Зазначені обставини тісно пов'язані з предметом доказування. Унауковій літературі останню категорію визначають по-різному: як систему (сукупність) фактів й обставин об'єктивної дійсності, що мають матеріально-правове (кримінальне й цивільне) та процесуальне (кримінальне й цивільне) значення $і$ які $\epsilon$ необхідною й достатньою фактичною підставою для вирішення кримінальних справ остаточно і по суті. Зроблено висновок, що предмет доказування у кримінальних провадженнях щодо злочинів, пов'язаних із зайняттям гральним бізнесом, деталізовано з урахуванням особливостей криміналістичної характеристики цієї категорії кримінальних правопорушень. На встановлення події злочину впливають: технологія, спосіб та місце зайняття гральним бізнесом, використане обладнання, категорії гравців. Винуватість обвинуваченого залежить від функції, яку він виконує у злочинній групі, виду та форми співучасті. Потребує встановлення розмір матеріальної шкоди, завданої гравцям в азартні ігри, а також напрями легалізації (відмивання) доходів, одержаних злочинним шляхом. Запропоновано поширити відповідальність за зайняття гральним бізнесом на всі категорії суб'єктів, які організовують та проводять азартні ігри з метою одержання прибутку, з унесенням відповідних змін і доповнень до Закону Украӥни «Про заборону грального бізнесу в Україні».
\end{abstract}


Ключові слова: гральний бізнес; азартна гра; кримінальні правопорушення, пов'язані із зайняттям гральним бізнесом; доказування; предмет доказування; подія кримінального правопорушення.

Актуальність теми. Із прийняттям законів України «Про заборону грального бізнесу в Україні» (2009р.) [1] та «Про внесення змін до деяких законодавчих актів України щодо удосконалення законодавства про заборону грального бізнесу в Україні» (2011р.) [2; 3] у нашій країні остаточно заборонено організацію, проведення та надання можливості доступу до азартних ігор, а також запроваджено низку обмежень і санкцій до суб'єктів господарювання, які здійснюють таку діяльність з метою одержання прибутку. Однак попри посилені заходи державно-правової протидії цьому соціально негативному явищу, зокрема шляхом запровадження до Кримінального кодексу (КК) України спеціальної норми (ст. 203-2), правоохоронці щороку викривають сотні тіньових гральних закладів у великих містах і курортних зонах, вилучають тисячі одиниць грального обладнання, виявляють мільйонні суми коштів, одержаних злочинним шляхом. Гральний бізнес дедалі спустошує гаманці громадян, утягуючи у свої нетрі як лудоманів (залежних від азартних ігор), так і нових жертв, зокрема неповнолітніх. За даними соціологічних опитувань, кожний четвертий 3 тих, хто програв, мав намір вчинити самогубство або вчиняв його [4].

Виклад основного матеріалу. Упродовж останніх років відбувається стрімке збільшення кількості суб'єктів та об’єктів грального бізнесу, що технологічно пов'язаний з учиненням інших злочинів проти власності, у сфері господарської діяльності, кіберзлочинів тощо. Згідно з інформацією МВС України, упродовж 2015-2018 рр. оперативними підрозділами опрацьовано близько 4 тис. звернень щодо неправомірного надання послуг у сфері грального бізнесу. Унаслідок вжитих заходів у цей період розпочато 996 кримінальних проваджень. 3 них направлено до суду 3 обвинувальними актами майже половину (48,9%), за якими в 51,0% проваджень, тобто лише за кожним четвертим виявленим фактом зайняття гральним бізнесом, винесено обвинувальні вироки, а винуватих притягнуто до кримінальної відповідальності. Низьку результативність роботи на цьому важливому напрямі зумовлено, насамперед, об'єктивними складнощами збирання доказів, адже суб'єкти грального бізнесу зазвичай ретельно планують свої дії, кваліфіковано приховують сліди злочинів, застосовують корупційне прикриття. Відсутність у слідчих та оперативних працівників належного досвіду розслідування зайняття гральним бізнесом потребує відповідного науково-методичного забезпечення [5].

Для розслідування злочинів, пов'язаних із зайняттям гральним бізнесом, важливе значення має розроблення обставин, що підлягають доказуванню. Зазначені обставини тісно пов'язані 3 предметом доказування. У науковій літературі останню категорію визначають порізному: як систему (сукупність) фактів й обставин об'єктивної дійсності, що мають матеріально-правове (кримінальне й цивільне) та процесуальне (кримінальне й цивільне) значення і які $\epsilon$ необхідною й достатньою фактичною підставою для вирішення кримінальних справ остаточно і по суті (В.0. Попелюшко) [6, с. 48]; сукупність передбачених кримінально-про- 
цесуальним законом обставин, встановлення яких необхідне для вирішення заяв і повідомлень про злочин, кримінальної справи загалом або судової справи на стадії виконання вироку, а також для вживання процесуальних профілактичних заходів у справі (М.М. Михеєнко) [7, с. 89]; систему фактів (обставин), необхідних і достатніх як підстава для застосування норм матеріального (кримінального і цивільного) і кримінально-процесуального права під час вирішення кримінальної справи (А. М. Ларін) [8, с. 259]. Такі визначення трапляються і в інших дослідженнях.

C. С. Чернявський проаналізував співвідношення криміналістичної характеристики злочинів i предмета доказування. По-перше, сутність предмета доказування чітко визначено кримінально-процесуальним законом, що регламентує вичерпний перелік відповідних структурних елементів, необхідних і достатніх, на думку законодавця, для встановлення істини в будьякій справі. Предмет доказування - категорія стала, законодавчо визначена, універсальна щодо застосування. Водночас криміналістична характеристика злочинів $є$ результатом узагальнення й аналізу кримінальних проваджень, а пропозиції, що грунтуються на цих дослідженнях, мають рекомендаційний характер, оскільки зв'язки між елементами криміналістичної характеристики завжди $є$ ймовірнісно-статистичними. Тобто криміналістична характеристика злочинів - категорія наукова, більш динамічна і спеціальна у плані застосування. По-друге, у криміналістичній характеристиці злочинів зібрано не власне обставини, що становлять предмет доказування, а відомості про них, і лише ті, що містять криміналістично значиму інформацію (наприклад, деякі обставини, що впливають на ступінь і характер відповідальності, є складовою предмета доказування, але не мають криміналістичного значення). Натомість криміналістична характеристика значно ширша за предмет доказування, оскільки охоплює дані, що можуть мати проміжне пошукове значення для розслідування, або виконувати роль логічних аргументів. По-третє, предмет доказування та криміналістична характеристика злочинів - поняття не тотожні, що не поглинають одне одного. Перше з них є категорією науки кримінального процесу та стосується процесу доказування, друге - категорією криміналістичної методики та сприяє правильному визначенню засобів і методів організації пошуково-пізнавальної діяльності для встановлення невідомих обставин у справі.

Розглядаючи співвідношення понять «предмет доказування» й «обставини, що підлягають встановленню», дослідник зауважив на декількох важливих положеннях. По-перше, за етимологією, «обставина» буквально означає: «явище, подія чи факт, що пов'язані з чим-небудь, супроводжують що-небудь». Йдеться про дійсні події, явища або процеси, тобто про те, що фактично відбулось. Натомість предмет доказування у кримінальній справі чітко визначений кримінально-процесуальним законодавством і $є$ незмінною конструкцією (абстракцією), елементи якої, на думку законодавця, є достатніми для встановлення істини в будь-якій справі. По-друге, «обставини, що підлягають встановленню», $є$ категорією криміналістичної методики, а перелік цих обставин наповнюється конкретним змістом і залежить від видової (групової) характеристики злочинів, а також конкретної ситуації розслідування. Цей перелік, поряд із прямими доказами, включає в себе різноманітну криміналістично значущу 
інформацію (проміжні факти й обставини), що виходить за межі предмета доказування, проте має чітке пошуково-пізнавальне спрямування, визначають напрям розслідування [9, с. 327-328].

Згідно зі ст. 91 КПКУкраїни, у кримінальному провадженні підлягають доказуванню такі обставини:

1) подія кримінального правопорушення (час, місце, спосіб та інші обставини вчинення кримінального правопорушення);

2) винуватість обвинуваченого у вчиненні кримінального правопорушення, форма вини, мотив і мета вчинення кримінального правопорушення;

3) вид і розмір шкоди, завданої кримінальним правопорушенням, а також розмір процесуальних витрат;

4) обставини, які впливають на ступінь тяжкості вчиненого кримінального правопорушення, характеризують особу обвинуваченого, обтяжують чи пом'якшують покарання, що виключають кримінальну відповідальність або є підставою закриття кримінального провадження;

5) обставини, що є підставою для звільнення від кримінальної відповідальності або покарання [10].

Оскільки злочини, пов'язані із зайняттям гральним бізнесом, за способами вчинення, знаряддями та засобами, що при цьому використовуються, найбільш подібні до кримінальних правопорушень у сфері використання електронно-обчислювальних машин, варто дослідити головні обставини, що підлягають встановленню при розслідуванні кримінальних правопорушень у сфері використання комп'ютерів, систем та комп'ютерних мереж.

У криміналістичній літературі до таких обставин належать:

1) час вчинення злочину;

2) місце вчинення злочину;

3) особливості й характеристика об'єкта, на якому вчинено злочин;

4) особливості побудови й організації експлуатації засобів обчислювальної техніки;

5) спосіб злочинного впливу на інформацію;

6) характеристика інформації, що зазнала злочинного впливу;

7) засоби, які використовувались при вчиненні злочину;

8) спосіб подолання програмного й апаратного захисту;

9) можливість вчинення злочину ззовні приміщення через мережі телекомунікації та наявність слідів у вигляді протоколів обміну й іншої комп'ютерної інформації;

10) наявність можливості проникнення на місце злочину і відходу від нього через вікно, двері, пролом, сходи, а також способи відходу (пішки або з використанням транспортного засобу);

11) наявність на об'єкті, шляхах підходу і відходу слідів злочину і злочинця;

12) знаряддя злочину (використане для проникнення на об'єкт і (або) застосоване для розкриття і демонтажу пристроїв обчислювальної техніки), його частини і сліди (їх характеристика, індивідуальні ознаки, спосіб виготовлення, місце придбання, виготовлення, зберігання i минулого використання); 
13) наявність слідів підготовчих дій до вчинення злочину;

14) мета і мотиви вчинення злочину;

15) наявність кваліфікуючих ознак злочину у сфері використання EОМ (комп'ютерів), систем та комп'ютерних мереж;

16) відомості про суб'єкт (суб'єкти) злочину;

17) наявність співучасників;

18) ознаки організованої групи;

19) наявність на одязі особи, яка вчинила злочин, при ній або в помешканні слідів і знарядь злочину або його частин (інструменти, аналоги матеріалів, з яких виготовлялося знаряддя злочину, мікрочастинки з місця вчинення злочину, тілесні ушкодження, отримані при проникненні на об'єкт);

20) наявність в особи, яка вчинила злочин, родичів і знайомих викрадених засобів обчислювальної техніки, інформації на машинних носіях або інших слідів (документів і частин викраденого, що залишилися при зберіганні, грошей, цінностей і документів, отриманих при збуті);

21) факт збуту викраденого даною особою, її родичами або знайомими;

22) наявність у цих осіб транспортних засобів для перевезення викраденого;

23) вид і розмір збитку (фізичного, матеріального, морального), кому заподіяний і обставини його відшкодування;

24) винність особи, яка вчинила злочин;

25) причини та умови, що сприяли вчиненню злочину;

26) дані, що впливають на характер і міру відповідальності;

27) збіг або невідповідність відомостей про вищезгаданих осіб наявним відомостям про особу злочинця;

28) місцезнаходження особи або осіб, які становлять інтерес, у момент вчинення злочину (причини відсутності за місцем роботи, навчання і вдома).

3'ясування цих обставин здійснюється шляхом проведення слідчих (розшукових) дій та оперативно-розшукових заходів $[11$, с. 198-201; 12, c. 14-18].

Водночас у кримінальному провадженні за злочинами, пов'язаними із зайняттям гральним бізнесом, підлягають доказуванню:

1) подія кримінального правопорушення (час, місце, спосіб та інші обставини вчинення кримінального правопорушення). Ця група обставин має на меті вирішення таких орієнтовних питань: чи має подія злочинний характер (вчинено злочин чи адміністративне правопорушення, які саме); який механізм злочинної події (дії щодо підготовки, вчинення та приховування злочину); у чому полягали дії злочинця щодо організації, проведення азартних ігор та надання можливості доступу до них; коли і де організовано гральний бізнес; який період продовження злочинних дій; який вид азартних ігор організовано; яке гральне обладнання використовувалось для зайняття гральним бізнесом; хто $\epsilon$ потерпілим (потерпілими) від злочину; хто $\epsilon$ учасниками азартних ігор; хто вчинив злочин, чи $є$ ця особа осудною; кількість злочинців, характер стосунків членів злочинної групи; чи мав місце розподіл ролей, у чому полягали дії кожного учасника злочинної групи; спеціальні 
ознаки злочинців, їх соціально-психологічні особливості [13, с. 152-153].

Серед відомостей про суб'єкт (суб’єкти) злочину підлягають встановленню такі дані: вік, осудність, ознаки зовнішності, навички, інтереси, схильності, професійні вміння, стан сп'яніння в момент вчинення злочину. Крім того, необхідно встановити наявність співучасників: їх біографічні дані; їх роль у злочині (виконавець, організатор, підбурювач, пособник); конкретні дії кожного співучасника, ознаки, що характеризують ту чи іншу форму співучасті (кількість співучасників, розподіл функцій та ролей, стійкість, попередню змову чи зорганізованість, мету діяльності, наявність плану тощо);

2) винуватість обвинуваченого у вчиненні кримінального правопорушення, форма вини, мотив і мета вчинення кримінального правопорушення.

Ця група обставин має на меті вирішення таких орієнтовних питань: чи винна особа у вчиненні злочину; яка форма ї̈ вини, мотив і мета його вчинення. обов'язково необхідно з'ясувати, який прибуток отримував злочинець, яким чином, який його розмір; як він розподілявся між іншими співучасниками грального бізнесу;

3) вид і розмір шкоди, завданої кримінальним правопорушенням, а також розмір процесуальних витрат. Злочини, пов'язані із зайняттям гральним бізнесом, не спричиняють матеріальної шкоди. Стосовно розміру процесуальних витрат, то тут обов'язкового необхідно включати витрати на проведення комп'ютерно-технічної експертизи;

4) обставини, які впливають на ступінь тяжкості вчиненого кримінального правопорушення, характеризують особу обвинуваченого, обтяжують чи пом'якшують покарання, які виключають кримінальну відповідальність або є підставою закриття кримінального провадження;

5) обставини, що $є$ підставою для звільнення від кримінальної відповідальності або покарання. Ще А. М. Ларін вважав за необхідне віднести до предмета доказування підстави для закриття справи, а також пропонував включити пункт, згідно з яким доказуванню підлягають обставини, що $\epsilon$ підставами до звільнення обвинуваченого від кримінальної відповідальності або закриття справи в цілому [14, с 62].

Здебільшого щодо цієї категорії кримінальних проваджень мають місце обставини, що пом'якшують покарання, зокрема щире каяття, активне сприяння в розкритті злочину, наявність на утриманні неповнолітніх дітей, догляд за важко хворими рідними, складне матеріальне становище сім'ї, збіг тяжких особистих обставин.

3 огляду на те, що злочин, передбачений ст. 203-2 КК України, належить до категорії особливо тяжких. до особи, яка його вчинила, може бути застосовано лише звільнення від кримінальної відповідальності у зв'язку із закінченням строків давності (ст. 49 КК України).

Відповідно до ч. 5 ст. 12 КК України, особливо тяжким злочином $є$ злочин, за який передбачено основне покарання у виді штрафу в розмірі понад двадцять п'ять тисяч неоподатковуваних мінімумів доходів громадян, позбавлення волі на строк понад десять років або довічного позбавлення волі. Водночас ч. 1 ст. 203-2 КК України передбачає покарання у вигляді штрафу від десяти тисяч до сорока тисяч неоподатковуваних мінімумів доходів громадян з конфіскацією грального обладнання, а ч. 2 цієї статті - 
штраф у розмірі від сорока тисяч до п’ятдесяти тисяч неоподатковуваних мінімумів доходів громадян з конфіскацією грального обладнання.

Під час документування ознак зайняття гральним бізнесом найбільші труднощі викликає встановлення таких обставин, як винність обвинуваченого у вчиненні кримінального правопорушення, форма вини, мотив і мета здійснення кримінального правопорушення (68,2 \%); подія кримінального злочину (час, місце, спосіб та інші обставини скоєння кримінального правопорушення) (57,6 \%); обставини, що є підставою для звільнення від кримінальної відповідальності або покарання (27,8 \%); обставини, що впливають на ступінь тяжкості вчиненого кримінального злочину, характеризують особу обвинуваченого, що обтяжують або пом'якшують покарання, що виключають кримінальну відповідальність або $\epsilon$ підставою для закриття кримінального провадження $(11,3$ \%); вид і розмір шкоди, заподіяної кримінальним правопорушенням, а також розмір процесуальних витрат $(9,2 \%)$.

Предмет доказування у кримінальних провадженнях щодо злочинів, пов'язаних із зайняттям гральним бізнесом, деталізовано з урахуванням особливостей криміналістичної характеристики цієї категорії кримінальних правопорушень. На встановлення події злочину впливають: технологія, спосіб та місце зайняття гральним бізнесом, використане обладнання, категорії гравців. Винуватість обвинуваченого залежить від функції, яку він виконує у злочинній групі, виду та форми співучасті. Потребує встановлення розмір матеріальної шкоди, завданої гравцям в азартні ігри, а також напрями легалізації (відмивання) доходів, одержаних злочинним шляхом. Запропоновано поширити відповідальність за зайняття гральним бізнесом на всі категорії суб’єктів, які організовують та проводять азартні ігри з метою одержання прибутку, з унесенням відповідних змін і доповнень до Закону України «Про заборону грального бізнесу в Україні».

\section{СПИСОК ВИКОРИСТАНИХ ДЖЕРЕЛ}

1. Про заборону грального бізнесу в Україні : Закон України від 15 трав. 2009 р. № 1334-VI. URL: http://zakon2.rada.gov.ua/laws/show/ 1334-17

2. Про внесення змін до деяких законодавчих актів України щодо удосконалення законодавства про заборону грального бізнесу в Україні : Закон України від 22 груд. 2010 р. № 2852-VI. URL: http://zakon3.rada.gov. ua/laws/show/2852-17

3. Про внесення змін до деяких законодавчих актів України щодо гуманізації відповідальності за правопорушення у сфері господарської діяльності : Закон України від 15 листоп. 2011 р. № 4025-VI. URL: http:// zakon4.rada.gov.ua/laws/show/4025-17

4. Гральний бізнес втік до Інтернету. Тема. URL: http://tema.in.ua/ article/5069.html.

5. Пиняга Р. О. Проблемні питання виявлення та розслідування злочинів, пов'язаних із зайняттям гральним бізнесом. Вісник Луганського державного університету внутрішніх справ імені Е. О. Дідоренка. 2013. Вип. 6. С. 77-87. 
6. Попелюшко В. Предмет доказування в кримінальному процесі (процесуально-правові та кримінально-правові аспекти). Острог, 2001. $196 \mathrm{c}$.

7. Михеєнко М. М. Проблеми розвитку кримінального процесу в Україні: Вибрані твори. К. : Юрінком Інтер, 1999. 240 с.

8. Строгович М. С., Алексеева Л. Б., Ларин А. М. Советский уголовнопроцессуальный закон и проблемы его эффективности / Строгович М. С. М. : Наука, 1979. 320 с.

9. Чернявський С. С. Теоретичні та практичні основи методики розслідування фінансового шахрайства : дис. ... доктора юрид. наук : 12.00.09. К., 2010. 610 с.

10. Кримінальний процесуальний кодекс України. Науковопрактичний коментар / за заг. ред. проф. В. Г. Гончаренка, В. Т. Нора, М. Є. Шумила. К. : Юстініан, 2012. 1224 с.

11. Голубев В. О., Гавловський В. Д., Цимбалюк В. С. Інформаційна безпека: проблеми боротьби зі злочинами у сфері використання комп'ютерних технологій. Запоріжжя : Просвіта, 2001. С. 198-201.

12. Особливості проведення огляду місця події при вчиненні комп'ютерних злочинів : навч.-метод. рек. / Дяченко Н. М., Корнійко С. М., Княждвірський В. О. Київ, 2007. 42 с.

13. Пиняга Р. О. Обстоятельства, подлежащие доказыванию при расследовании преступлений, связанных с занятим игорным бизнесом (анализ уголовно-процессуального законодательства Украины) / P. О. Пиняга // Актуальные проблемы науки, практики и вероисповеданий на современном этапе : сб. материалов одиннадцатой заоч. междунар. науч.-практ. конф. (Красноярск, Россия, 27 февр. 2013 г.) / под ред. проф., акад. РАЮН А. Н. Попова. Красноярск, 2013. Вып. 1. С. 151-153.

14. Ларин А. М. Расследование по уголовному делу. Планирование, организация. М. : Юрид. лит., 1970. 224 с.

\section{R. Pyniaha}

\section{CIRCUMSTANCES TO BE PROVED AT THE INITIAL STAGES OF INVESTIGATION OF CRIMINAL OFFENSES, RELATED TO THE GAMING BUSINESS}

The article details the subject of evidence, taking into account the forensic characteristics of criminal offenses related to gambling. It is determined that the event of a criminal offense includes, first of all, the technology and method of engaging in the gambling business, the time and place of its commission. Establishing the guilt of the accused, the form of guilt, motive and purpose of the crime aims to determine the number of persons involved in the crime, the nature of the distribution of roles between them, data on the defendants (age, sanity, appearance, professional skills), other signs that characterize one or another form of complicity (number of accomplices, resilience, prior conspiracy or organization, purpose of activity, availability of a plan). It is also necessary to establish a way to legalize proceeds of crime. It has been found that in order to investigate crimes related to the gambling business, it is important to develop the circumstances to 
be proved. These circumstances are closely related to the subject of proof. In the scientific literature, the latter category is defined differently: as a system (set) of facts and circumstances of objective reality, which have substantive (criminal and civil) and procedural (criminal and civil) significance and which are necessary and sufficient factual basis for resolution of criminal cases finally and in essence. It is concluded that the subject of evidence in criminal proceedings for crimes related to the gambling business is detailed taking into account the peculiarities of the forensic characteristics of this category of criminal offenses. The establishment of the crime scene is influenced by: technology, method and place of gambling, equipment used, categories of players. The guilt of the accused depends on the function he performs in the criminal group, the type and form of complicity. It is necessary to establish the amount of material damage caused to gamblers, as well as the direction of legalization (laundering) of proceeds from crime. It is proposed to extend the responsibility for gambling to all categories of entities that organize and conduct gambling for profit, with appropriate amendments to the Law of Ukraine «On Prohibition of Gambling in Ukraine».

Keywords: gambling business; gamble; criminal offenses related to gambling; proving; subject of proof; event of a criminal offense. 